\title{
Crystal structure and lithium diffusion pathways of a potential positive electrode material for Lithium-ion batteries: $\mathrm{Li}_{2} \mathrm{~V}^{\prime \prime \prime}\left(\mathrm{H}_{0.5} \mathrm{PO}_{4}\right)_{2}$
}

\author{
Edouard Boivin, ${ }^{a, b, c}$ Christian Masquelier, ${ }^{a, c, d}$ Laurence Croguennec, ${ }^{b, c, d}$ and Jean-Noël \\ Chotard $*, a, c, d$
}

${ }^{a}$ Laboratoire de Réactivité et de Chimie des Solides, CNRS-UMR\#7314,

Université de Picardie Jules Verne, F-80039 Amiens Cedex 1, France.

${ }^{\mathrm{b}}$ CNRS, Univ. Bordeaux, Bordeaux INP, ICMCB UPR 9048, F-33600 Pessac, France.

${ }^{\text {c }}$ RS2E, Réseau Français sur le Stockage Electrochimique de l'Energie, FR CNRS 3459,F-80039 Amiens Cedex 1, France.

${ }^{d}$ ALISTORE-ERI European Research Institute, FR CNRS 3104, F-80039 Amiens Cedex 1, France.

Supporting Information Placeholder

\begin{abstract}
A new potentially interesting material as positive electrode for $\mathrm{Li}$-ion batteries, $\mathrm{Li}_{2} \mathrm{~V}^{\mathrm{III}}\left(\mathrm{H}_{0.5} \mathrm{PO}_{4}\right)_{2}$, was obtained by hydrothermal synthesis. Its crystal structure was solved thanks to single crystal X-Ray diffraction. This material is isostructural to $\mathrm{Li}_{2} \mathrm{Fe}^{\mathrm{III}}\left(\mathrm{PO}_{4}\right)\left(\mathrm{HPO}_{4}\right)$, and also closely related to $\mathrm{Li}_{2} \mathrm{Fe}^{\mathrm{II}}\left(\mathrm{SO}_{4}\right)_{2}$. It can be described as $\mathrm{VO}_{6}$ octahedra sharing corners with six $\mathrm{PO}_{4}$ tetrahedra to form a three-dimensional framework. One oxygen atom of each phosphate group is unshared with a vanadium octahedron and as such linked to an hydrogen atom. The arrangement of these polyhedra generates large channels running along [100] in which lithium cations are located. The close structural relationship between $\mathrm{Li}_{2} \mathrm{Fe}^{\mathrm{III}}\left(\mathrm{PO}_{4}\right)\left(\mathrm{HPO}_{4}\right)$ and $\mathrm{Li}_{2} \mathrm{Fe}^{\mathrm{II}}\left(\mathrm{SO}_{4}\right)_{2}$ allows to investigate, by comparison, the effect of the hydrogen atoms lying on lithium diffusion pathways.
\end{abstract}

The development of new positive electrode materials for high energy density Lithium-ion batteries is one of the main issues for research in the field. Polyanionic compounds $\left(\mathrm{A}_{\mathrm{x}} \mathrm{M}_{\mathrm{y}}\left(\mathrm{XO}_{4}\right)_{\mathrm{z}}{ }^{1}\right)$ became the subject of intense research since the discovery by J.B. Goodenough and coworkers of reversible Lithium extraction/insertion from/in the olivine-type $\mathrm{LiFePO}_{4}{ }^{2}$. Indeed, this sustainable material demonstrates excellent chemical and thermal stability, as well as excellent cyclability even at high rates. Its main drawback is the low working voltage delivered $\left(3.45 \mathrm{~V}\right.$ vs. $\left.\mathrm{Li}^{+} / \mathrm{Li}\right)$ and thus an energy density still limited for transport applications. The replacement of iron by vanadium, potentially stable at $\mathrm{V}^{2+}, \mathrm{V}^{3+}, \mathrm{V}^{4+}$ and $\mathrm{V}^{5+}$ oxidation states allows the expected exchange of several electrons per transition metal ${ }^{3}$ at a higher potential (i.e. $4.25 \mathrm{~V}$ for $\mathrm{V}^{3+} / \mathrm{V}^{4+}$ in $\mathrm{LiVPO}_{4} \mathrm{~F}^{4}$, for example) and might be a solution to enhance energy density. We report here the structure of a di-lithiated $\mathrm{V}^{\mathrm{III}}$ phase which is theoretically able to be oxidized to $\mathrm{V}^{\mathrm{V}}\left(\mathrm{PO}_{4}\right)\left(\mathrm{HPO}_{4}\right)$ for a capacity of $210 \mathrm{mAh} / \mathrm{g}$.

$\mathrm{Li}_{2} \mathrm{~V}\left(\mathrm{H}_{0.5} \mathrm{PO}_{4}\right)_{2}$ was obtained by hydrothermal synthesis in similar conditions than those used for the synthesis of the isostructural iron-containing composition ${ }^{5}$. The reaction was carried out by mixing $\mathrm{VCl}_{3}$ (97\%, Sigma-Aldrich), $\mathrm{LiH}_{2} \mathrm{PO}_{4}$ (> $99 \%$, Sigma-Aldrich), and $\mathrm{Li}_{2} \mathrm{~B}_{4} \mathrm{O}_{7}(>99.9 \%$, Sigma-Aldrich) with a molar ratio of 1:5:1 in aqueous solution, in a $23 \mathrm{ml}$ Teflon container with a filling rate of $60 \%$. The reactor was introduced in an oven and heated at $220^{\circ} \mathrm{C}$ for two weeks with heating and cooling rates of $5^{\circ} \mathrm{C} / \mathrm{h}$. The brown-green powder obtained was filtered, washed with distilled water and then with ethanol and dried at $60^{\circ} \mathrm{C}$ in an oven overnight. This powder contained both $\mathrm{Li}_{2} \mathrm{~V}\left(\mathrm{H}_{0.5} \mathrm{PO}_{4}\right)_{2}$ and $\mathrm{LiVPO}_{4} \mathrm{OH}$ in a weight ratio 60/40 (Fig. S1) and no boron-based impurity was identified, despite the presence of Lithium tetraborate in the starting mixture. Note that this precursor might promote the formation of $\mathrm{Li}_{2} \mathrm{~V}\left(\mathrm{H}_{0.5} \mathrm{PO}_{4}\right)_{2}$ vs $\mathrm{LiVPO}_{4} \mathrm{OH}$ as we observed that without $\mathrm{Li}_{2} \mathrm{~B}_{4} \mathrm{O}_{7}$, under similar conditions, a pure $\mathrm{LiVPO}_{4} \mathrm{OH}$ was obtained ${ }^{6}$. Single crystals of the new composition $\mathrm{Li}_{2} \mathrm{~V}\left(\mathrm{H}_{0.5} \mathrm{PO}_{4}\right)_{2}$ were selected from the mixture. a)

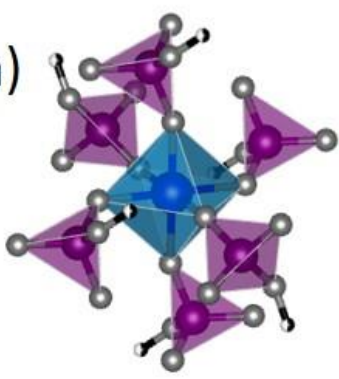

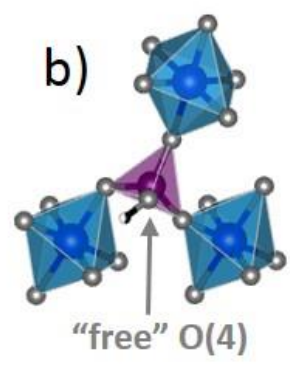

Figure 1: Polyhedra in the structure of $\mathrm{Li}_{2} \mathrm{~V}\left(\mathrm{H}_{0.5} \mathrm{PO}_{4}\right)_{2}$. The distribution of $\mathrm{PO}_{4}$ tetrahedra surrounding a $\mathrm{VO}_{6}$ octahedron is illustrated in (a) and conversely in (b).

Single crystal diffraction data were obtained on a Bruker D8 Venture diffractometer equipped with a Photon 100 detector and a Molybdenum micro-source $(\lambda=0.71073 \AA)$ at $293 \mathrm{~K}$. The crystal used for the diffraction experiment was a green parallelepiped $(0.14 * 0.09 * 0.07 \mathrm{~mm})$. The details for the data collection and the refinements are provided in supplementary information (Table $\mathrm{S} 1$ ).

$\mathrm{Li}_{2} \mathrm{~V}\left(\mathrm{H}_{0.5} \mathrm{PO}_{4}\right)_{2}$ crystalizes in a monoclinic unit cell $(\mathrm{a}=$ 4.8093(6) $\AA, \mathrm{b}=8.0070(9) \AA, \mathrm{c}=7.8485(9) \AA, \beta=112.395(6)^{\circ}, \mathrm{V}$ $=279.51(2) \AA^{3}$ and $\left.Z=2\right)$ described in the P2 $1 / \mathrm{c}($ S.G.\#14) space group. The crystal structure of $\mathrm{Li}_{2} \mathrm{~V}\left(\mathrm{H}_{0.5} \mathrm{PO}_{4}\right)_{2}$ (illustrated in fig. 1 and fig. 2 , with the atomic positions listed in table 1 , the anisotropic atomic displacement parameters in table $\mathrm{S} 2$ and the selected interatomic distances and angles in table S3) is characterized by $\mathrm{VO}_{6}$ octahedra sharing corners with six $\mathrm{PO}_{4}$ tetrahedra (fig. 1a) forming a 3-D network while each $\mathrm{PO}_{4}$ tetrahedron shares three corners with three $\mathrm{VO}_{6}$ octahedra (fig. 1b). Vanadium is located on the inversion 
center of $\mathrm{VO}_{6}$ octahedra and $\mathrm{V}-\mathrm{O}$ bond distances range from $1.974(2) \AA$ to $2.031(2) \AA$ forming slightly distorted entities $\left(\Delta=1.11 \times 10^{-4}\right)$. The bond valence sum of vanadium is in very good agreement with the formation of a $\mathrm{V}^{3+}$-containing phase (i.e. $\mathrm{BVS}(\mathrm{V})=2.95(1))$. The $\mathrm{PO}_{4}$ tetrahedra are quite rigid groups $(\Delta=$ $2.96 \times 10^{-5}$ ) in which the distances range from 1.523(2) to $1.546(2)$ $\AA$, in very good agreement with distances commonly found in phosphate groups ${ }^{7}$.

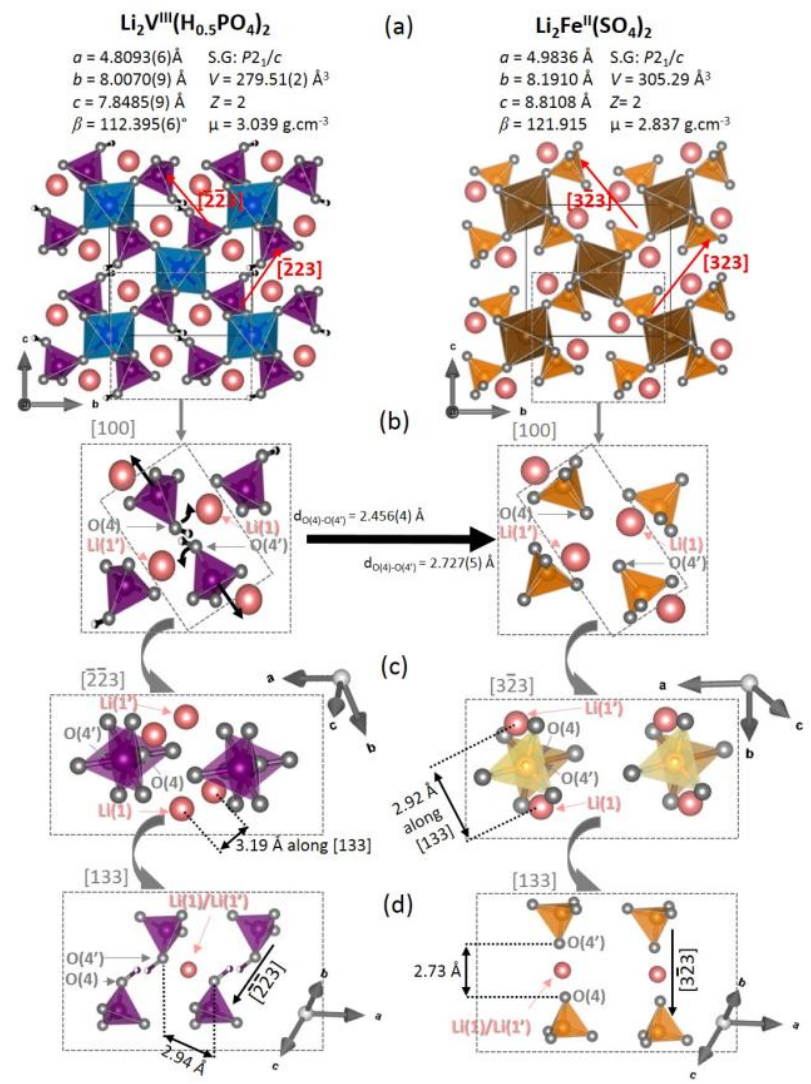

Figure 2: Structural relationship between $\mathrm{Li}_{2} \mathrm{~V}\left(\mathrm{H}_{0.5} \mathrm{PO}_{4}\right)_{2}$ (left) and $\mathrm{Li}_{2} \mathrm{Fe}\left(\mathrm{SO}_{4}\right)_{2}$ (right). The whole structure in (a) and an enlargement of the $\mathrm{H}\left(\mathrm{PO}_{4}\right)_{2}$ or $\left(\mathrm{SO}_{4}\right)_{2}$ groups in (b) are projected along [100]. The same groups are projected along the $\mathrm{O}(4)-\mathrm{O}\left(4^{\prime}\right)$ direction in (c) (i.e. [ $\overline{22} 3]$ and [32 3 ] for $\mathrm{Li}_{2} \mathrm{~V}\left(\mathrm{H}_{0.5} \mathrm{PO}_{4}\right)_{2}$ and $\mathrm{Li}_{2} \mathrm{Fe}\left(\mathrm{SO}_{4}\right)_{2}$ respectively ) and along the shorter Li-Li distance in (d) (i.e. [133]). On that latter, the smaller section of the path for lithium hopping between two closest sites is depicted.

Thanks to Fourier difference maps, a peanut-shape residual electronic density was found between the $\mathrm{O}(4)$ and its equivalent by centrosymmetry $\mathrm{O}\left(4^{\prime}\right)$ (Fig. S3). Those two oxygen atoms belong to two different $\mathrm{PO}_{4}$ and unshared with $\mathrm{VO}_{6}$. In the following, these oxygen atoms will be called "free" oxygens. The hydrogen atom position was thus fixed to the center of each lobe in a $4 \mathrm{e}$ site $(0.45$, $0.51,0.01$ ) half occupied generating an $\mathrm{O}-\mathrm{H}$ interatomic distance of 1.018(2) A commonly observed for hydroxyl group. This position is very close to the one found by Jin-Xiao Mi et al. ${ }^{5}$ for the iron phase (i.e. $0.45,0.52,0.02$ ). A more extended discussion about the hydrogen position is provided in supporting information.

As mentioned earlier, $\mathrm{Li}_{2} \mathrm{~V}\left(\mathrm{H}_{0.5} \mathrm{PO}_{4}\right)_{2}$ is isostructural to $\mathrm{Li}_{2} \mathrm{Fe}\left(\mathrm{PO}_{4}\right)\left(\mathrm{HPO}_{4}\right)$, but is also closely related to the Marinite structure of $\mathrm{Li}_{2} \mathrm{Fe}^{\mathrm{II}}\left(\mathrm{SO}_{4}\right)_{2}{ }^{8}$. The relations between $\mathrm{Li}_{2} \mathrm{~V}\left(\mathrm{H}_{0.5} \mathrm{PO}_{4}\right)_{2}$ and $\mathrm{Li}_{2} \mathrm{Fe}\left(\mathrm{SO}_{4}\right)_{2}$ are illustrated in figure 2 . The essential differences reside in the orientation of $\mathrm{XO}_{4}$ groups $(\mathrm{X}=\mathrm{P}, \mathrm{S})$ and in the distance between 2 "free" oxygen atoms. These distances are 2.727(5) $\AA$ in $\mathrm{Li}_{2} \mathrm{Fe}\left(\mathrm{SO}_{4}\right)_{2}$ vs $2.456(2) \AA$ in $\mathrm{Li}_{2} \mathrm{~V}\left(\mathrm{H}_{0.5} \mathrm{PO}_{4}\right)_{2}$. The shorter $\mathrm{O}(4)-$
$\mathrm{O}\left(4^{\prime}\right)$ distance in $\mathrm{Li}_{2} \mathrm{~V}\left(\mathrm{H}_{0.5} \mathrm{PO}_{4}\right)_{2}$ can be explained by the presence of hydrogen which screens the electrostatic repulsion between these two "free" oxygen atoms. This shortening leads to a shrinking of the structure and to a decrease of the section of the channel running along [100] in which $\mathrm{Li}^{+}$can diffuse. Figures $2 \mathrm{c}$ and $2 \mathrm{~d}$ illustrate the differences in $\mathrm{XO}_{4}(\mathrm{X}=\mathrm{P}$ or $\mathrm{S})$ orientations. Indeed the projection along [133] (fig 2d) corresponding to the direction of shorter $\mathrm{Li}-\mathrm{Li}$ distance in both materials reveals that the $\mathrm{Li}(1)-\mathrm{Li}\left(1^{\prime}\right)$ path doesn't intersect the $\mathrm{O}(4)-\mathrm{O}\left(4^{\prime}\right)$ segment in $\mathrm{Li}_{2} \mathrm{~V}\left(\mathrm{H}_{0.5} \mathrm{PO}_{4}\right)_{2}$ whereas it does in $\mathrm{Li}_{2} \mathrm{Fe}\left(\mathrm{SO}_{4}\right)_{2}$.

In order to get more insights into the possible pathways for Lithium diffusion, Bond Valence Energy Landscape (BVEL) maps were calculated thanks to the BONDSTR software in the Fullprof suite ${ }^{9}$ and drawn with VESTA ${ }^{10}$ in figure 3 . This empirical method uses Bond valence Sum to determine possible diffusion pathways considering a given minimum energy to activate the movement of $\mathrm{Li}^{+}$ions ${ }^{11}$. An energy of $1.6 \mathrm{eV}$ is often used for lithium diffusion in polyanionic compounds ${ }^{6}$ and it is interesting to compare the isosurfaces obtained for $\mathrm{Li}_{2} \mathrm{Fe}\left(\mathrm{SO}_{4}\right)_{2}$ and for $\mathrm{Li}_{2} \mathrm{~V}\left(\mathrm{H}_{0.5} \mathrm{PO}_{4}\right)_{2}$ in order to investigate the influence of the additional hydrogen atom on lithium diffusion. In the iron sulfate phase, this technique highlighted that lithium diffusion occurred along [100] [011] and [0-11] according to a 3D interconnected pathway (see also the figure $8 \mathrm{a}$ of ref. ${ }^{12}$ ). For $\mathrm{Li}_{2} \mathrm{~V}\left(\mathrm{H}_{0.5} \mathrm{PO}_{4}\right)_{2}$, lithium diffusion doesn't occur along these directions but via a zig-zag path along [012] and [0-12], hopping between two sites distant of $4.32 \AA$ (fig. 3), and leading to an overall diffusion direction along [001]. The comparison between both structures (fig. 3) illustrates that the presence of hydrogen in $\mathrm{Li}_{2} \mathrm{~V}\left(\mathrm{H}_{0.5} \mathrm{PO}_{4}\right)_{2}$ unables the diffusion along [100], [011] and [0-11]. At first sight, the inability for Li to diffuse along [011] and [0-11] in $\mathrm{Li}_{2} \mathrm{~V}\left(\mathrm{H}_{0.5} \mathrm{PO}_{4}\right)_{2}$ comes as a surprise because i) the shorter $\mathrm{Li}-\mathrm{Li}$ distance $(3.19 \AA)$ is found along those axis and ii) the section (2.94 $\AA$ ) is higher compare to the one found within the Marinite structure $(2.73 \AA)$ as depicted in fig. $2 \mathrm{~d}$ and S3. Actually, in both cases this space is already occupied by oxygen atoms or $\mathrm{OH}$ groups and the bypassing of this diffusion obstacle is forbidden in $\mathrm{Li}_{2} \mathrm{~V}\left(\mathrm{H}_{0.5} \mathrm{PO}_{4}\right)_{2}$ due to the presence of hydrogen that prevents the connection between the two pathways whereas it is possible in Marinite (fig. S3).

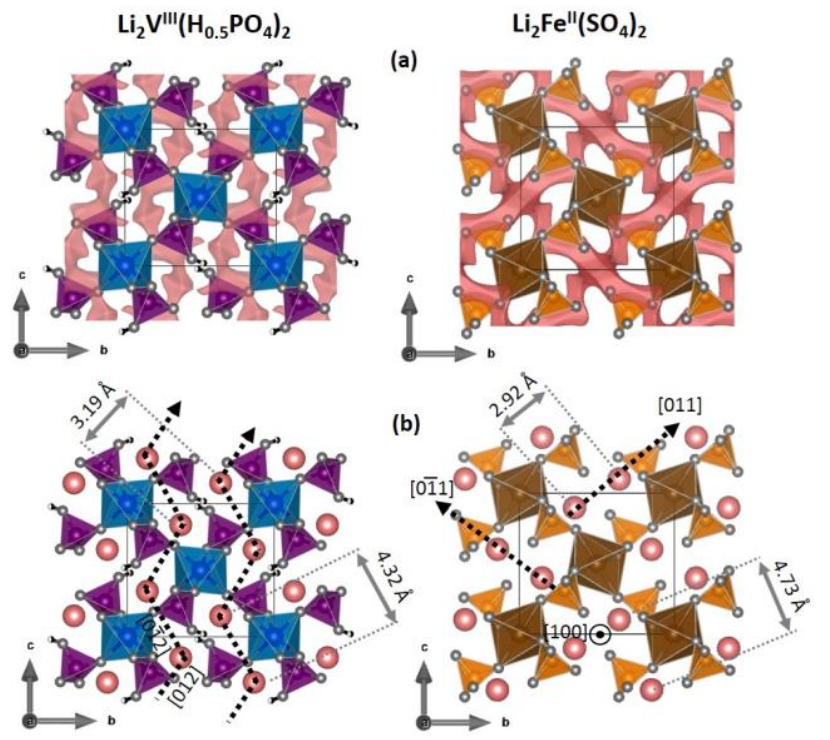

Figure 3: Projection along [100] of Lithium paths obtained from Bond Valence Energy Landscape (BVEL for $\mathrm{Li}_{2} \mathrm{Fe}\left(\mathrm{SO}_{4}\right)_{2}$ (right) and $\mathrm{Li}_{2} \mathrm{~V}\left(\mathrm{H}_{0.5} \mathrm{PO}_{4}\right)_{2}$ (left) and the corresponding lithium hopping between closest sites (b). 
Table 1. Cell parameters, fractional atomic coordinates, isotropic* or equivalent isotropic displacement parameters $\left(\AA^{2}\right)$ and Bond valence sum obtained from refinement of the crystal structure of $\mathrm{Li}_{2} \mathrm{~V}\left(\mathrm{H}_{0.5} \mathrm{PO}_{4}\right)_{2}$.

\begin{tabular}{|c|c|c|c|c|c|c|c|}
\hline \multicolumn{8}{|c|}{$\mathbf{L i}_{2} \mathbf{V}\left(\mathbf{H}_{0.5} \mathrm{PO}_{4}\right)_{2}$} \\
\hline $\mathrm{SG}: \mathrm{P} 2{ }_{1} / \mathrm{c}$ & $a=4.8093(6) \AA$ & $\mathrm{b}=8.0070(9) \AA$ & $\mathrm{c}=7.8485(9) \AA$ & $\beta=112.395(6)$ & $V=279.51($ & & \\
\hline $\mathrm{Z}=2$ & $\mathrm{R}_{\mathrm{int}}=5.9 \%$ & $\mathrm{wR}\left(\mathrm{F}^{2}\right) 6.7 \%$ & $\mathrm{R}\left[\mathrm{F}^{2}>2 \sigma\left(\mathrm{F}^{2}\right)\right.$ & $2.9 \%$ & $\mathrm{M}_{\mathrm{w}}=255.76 \mathrm{~g}$. & & $\mathrm{M}=3.039 \mathrm{~g} \cdot \mathrm{cm}^{-3}$ \\
\hline Atoms & Wyckoff & $\mathbf{x}$ & $\mathbf{y}$ & $\mathbf{z}$ & Occupancy & Uiso*/Ueq & BVS \\
\hline $\mathrm{V}(1)$ & $2 \mathrm{a}$ & 0 & 0 & 0 & 1.000 & 0.0046 & $2.94(1)$ \\
\hline $\mathrm{H}(1)$ & $4 \mathrm{e}$ & 0.45 & 0.51 & 0.01 & $1 / 2$ & $0.064 *$ & $1.20(1)$ \\
\hline $\mathrm{P}(1)$ & $4 \mathrm{e}$ & $0.6334(1)$ & $0.65234(6)$ & $0.76519(6)$ & 1.000 & 0.0048 & $5.02(1)$ \\
\hline $\mathrm{O}(1)$ & $4 \mathrm{e}$ & $0.2966(3)$ & $0.6733(2)$ & $0.6506(2)$ & 1.000 & 0.0078 & $2.00(1)$ \\
\hline $\mathrm{O}(2)$ & $4 \mathrm{e}$ & $0.7929(4)$ & $0.8203(2)$ & $0.8116(2)$ & 1.000 & 0.0092 & $2.05(1)$ \\
\hline $\mathrm{O}(3)$ & $4 \mathrm{e}$ & $0.7763(4)$ & $0.5433(2)$ & $0.6605(2)$ & 1.000 & 0.0087 & $2.05(1)$ \\
\hline $\mathrm{O}(4)$ & $4 \mathrm{e}$ & $0.6892(4)$ & $0.5595(2)$ & $0.9480(2)$ & 1.000 & 0.0102 & $2.06(1)$ \\
\hline $\mathrm{Li}(1)$ & $4 \mathrm{e}$ & $0.0466(9)$ & $0.8634(6)$ & $0.6569(9)$ & 1.000 & 0.0148 & $1.07(1)$ \\
\hline
\end{tabular}

In summary, a new composition, $\mathrm{Li}_{2} \mathrm{~V}^{\mathrm{III}}\left(\mathrm{H}_{0.5} \mathrm{PO}_{4}\right)_{2}$, was obtained under hydrothermal conditions and its structure was solved thanks to single crystal X-Ray diffraction. In this structure, $\mathrm{VO}_{6}$ octahedra share corners with six $\mathrm{PO}_{4}$ tetrahedra to form a three-dimensional framework. This crystallographic feature is also observed in LiV${ }^{\mathrm{III}} \mathrm{P}_{2} \mathrm{O}_{7}$ and prevents the formation of vanadyle bonds (i.e. of strongly covalent $\mathrm{V}=\mathrm{O}$ bonds for $\mathrm{V}^{4+}$ or $\mathrm{V}^{5+}$ ) in $\mathrm{V}^{\mathrm{IV}} \mathrm{P}_{2} \mathrm{O}_{7} .{ }^{13}$ Interestingly, the voltage of the $\mathrm{V}^{3+} / \mathrm{V}^{4+}$ redox couple in $\mathrm{LiVP}_{2} \mathrm{O}_{7}$ is located at a higher voltage of $4.2 \mathrm{~V} \mathrm{vs} \mathrm{Li}^{+} / \mathrm{Li}$, against $2.3 \mathrm{~V}$ in the vanadyle-rich compound $\mathrm{Li}_{2} \mathrm{VOPO}_{4}{ }^{14}$ Moreover, contrarily to $\mathrm{LiVP}_{2} \mathrm{O}_{7}$ in which the capacity is limited by the lithium content (i.e. $\mathrm{Li} / \mathrm{V}=1$ ), in $\mathrm{Li}_{2} \mathrm{~V}\left(\mathrm{H}_{0.5} \mathrm{PO}_{4}\right)_{2}$ the extraction of two $\mathrm{Li}$ per $\mathrm{V}$ is expected. It would involve first the $\mathrm{V}^{3+} / \mathrm{V}^{4+}$ redox couple (expected to be close to $4 \mathrm{~V}$ as for $\mathrm{LiVP}_{2} \mathrm{O}_{7}$ ) and then the $\mathrm{V}^{4+} / \mathrm{V}^{5+}$ redox couple at an higher potential, conferring to this material a very high theoretical energy density (up to $800 \mathrm{Wh} / \mathrm{kg}$ against $585 \mathrm{Wh} / \mathrm{kg}$ for $\mathrm{LiFePO}_{4}$ ). In $\mathrm{Li}_{2} \mathrm{~V}^{\mathrm{III}}\left(\mathrm{H}_{0.5} \mathrm{PO}_{4}\right)_{2}$, one oxygen atom of each phosphate group is unshared with vanadium octahedra and hydrogen atoms are located between two of them, forming an hydroxyl group involved in an hydrogen bond which disrupts the lithium diffusion. Indeed, the comparative study between $\mathrm{Li}_{2} \mathrm{~V}^{\mathrm{III}}\left(\mathrm{H}_{0.5} \mathrm{PO}_{4}\right)_{2}$ and $\mathrm{Li}_{2} \mathrm{Fe}^{\mathrm{II}}\left(\mathrm{SO}_{4}\right)_{2}$ by $\mathrm{BVEL}$ reveals that the hydrogen atom located inside the channels combined with the global shrinking of the structure forbids the diffusion along the [100], [0-11] and [011] directions in $\mathrm{Li}_{2} \mathrm{~V}^{\mathrm{III}}\left(\mathrm{H}_{0.5} \mathrm{PO}_{4}\right)_{2}$. That leads to a new diffusion path where lithium is hopping between two sites distant of $4.32 \AA$ along the [012] and [0-12] directions. Even if this study suggests a lower ionic conductivity in this material compared to the one of Marinite, its energy density, expected to be higher, makes it worth to further investigate its electrochemical properties. Prospective syntheses are in progress to obtain a pure phase powder.

\section{ASSOCIATED CONTENT}

\section{Supporting Information}

Single crystal data collection and refinement details, anisotropic displacement parameters and selected bond lengths and angles. Xray crystallographic data in CIF format for $\mathrm{Li}_{2} \mathrm{~V}\left(\mathrm{H}_{0.5} \mathrm{PO}_{4}\right)_{2}$ This material is available free of charge via the Internet at http://pubs.acs.org.

\section{AUTHOR INFORMATION}

\section{Corresponding Author}

*E-mail: jean-noel.chotard@u-picardie.fr

\section{ACKNOWLEDGMENT}

The authors acknowledge FEDER, the Région Picardie and the RS2E Network for the funding of EB's PhD thesis, as well as the financial support of the Région Nouvelle Aquitaine and of the French National Research Agency (STORE-EX Labex Project ANR-10-LABX-76-01 and HIPOLITE Progelec project ANR-12PRGE-0005-02).

\section{REFERENCES}

1. Masquelier, C. \& Croguennec, L. Polyanionic (phosphates, silicates, sulfates) frameworks as electrode materials for rechargeable Li (or Na) batteries. Chem. Rev. 2013, 113 (8), 6552-91.

2. Padhi, A. K., Nanjundaswamy, K. S. \& Goodenough, J. B. Phospho-olivines as Positive-Electrode Materials for Rechargeable Lithium Batteries. J. Electrochem. Soc. 1997, 144 (4), 2-8 (1997).

3. Ateba Mba, J., Masquelier, C., Suard, E. \& Croguennec, L. Synthesis and Crystallographic Study of Homeotypic $\mathrm{LiVPO}_{4} \mathrm{~F}$ and $\mathrm{LiVPO}_{4} \mathrm{O}$. Chem. Mater. 2012, $24,1223-1234$.

4. Barker, J., Saidi, M. Y. \& Swoyer, J. L. Electrochemical Insertion Properties of the Novel Lithium Vanadium Fluorophosphate, $\mathrm{LiVPO}_{4} \mathrm{~F}$. J. Electrochem. 2003, Soc. 150 (10), A1394.

5. Mi, J.-X. et al. Synthesis, Magnetism, and Crystal Structure of $\mathrm{Li}_{2} \mathrm{Fe}\left[\left(\mathrm{PO}_{4}\right)\left(\mathrm{HPO}_{4}\right)\right]$ and its Hydrogen Position Refinement. Zeitschrift für Anorg. und Allg. Chemie 2004, 630, 1632-1636.

6. Boivin, E.; Chotard, J.-N.; Ménétrier, M.; Bourgeois, L.; Bamine, T.; Carlier, D.; Fauth, F.; Suard, E.; Masquelier, C.; Croguennec, L. Structural and Electrochemical Studies of a New Tavorite Composition LiVPO4OH. J. Mater. Chem. A 2016, 4, 1103011045.

7. Huminicki, D. M. C.; Hawthorne, F. C. The Crystal Chemistry of the Phosphate Minerals. Rev. Mineral. Geochemistry 2002, 48 (1), 123-253.

8. $\quad$ Reynaud, M.; Ati, M.; Melot, B. C.; Sougrati, M. T.; Rousse, G.; Chotard, J.-N.; Tarascon, J.-M. Li2Fe(SO4)2 as a 3.83V Positive Electrode Material. Electrochem. commun. 2012, 21, 77-80. 
9. Rodriguez-carvajal, J. Recent Advances in Magnetic Structure Determination by Neutron Powder Diffraction. Phys. B 1993, 192, 55-69.

10. Momma, K.; Izumi, F. VESTA 3 for Three-Dimensional Visualization of Crystal, Volumetric and Morphology Data. J. Appl. Crystallogr. 2011, 44 (6), 1272-1276.

11. Adams, S. From Bond Valence Maps to Energy Landscapes for Mobile Ions in Ion-Conducting Solids. Solid State Ionics 2006, 177 (19-25), 1625-1630.

12. Lander, L.; Reynaud, M.; Carrasco, J.; Katcho, N. a; Bellin, C.; Polian, A.; Baptiste, B.; Rousse, G.; Tarascon, J.-M. Unveiling the Electrochemical Mechanisms of Li2Fe(SO4)2 Polymorphs by Neutron Diffraction and Density Functional Theory Calculations. Phys. Chem. Chem. Phys. 2016, 18 (21), 14509-14519.
13. Rousse, G.; Wurm, C.; Morcrette, M.; Rodriguez-carvajal, J.; Gaubicher, J.; Masquelier, C. Crystal Structure of a New Vanadium (IV) Diphosphate: VP2O7, Prepared by Lithium Extraction from LiVP2O7. Inorg. Mater. 2001, 3, 881-887.

14. Lin, Y.; Wen, B.; Wiaderek, K. M.; Sallis, S.; Liu, H.; Lapidus, S. H.; Borkiewicz, O. J.; Quackenbush, N. F.; Chernova, N. A.; Karki, K.; Omenya, F.; Chupas, P. J.; Piper, L. F. J.; Whittingham, M. S.; Chapman, K. W.; Ong, S. P. Thermodynamics, Kinetics and Structural Evolution of E-LiVOPO4 over Multiple Lithium Intercalation. chem. mater. 2016, 28, 1794-1805 

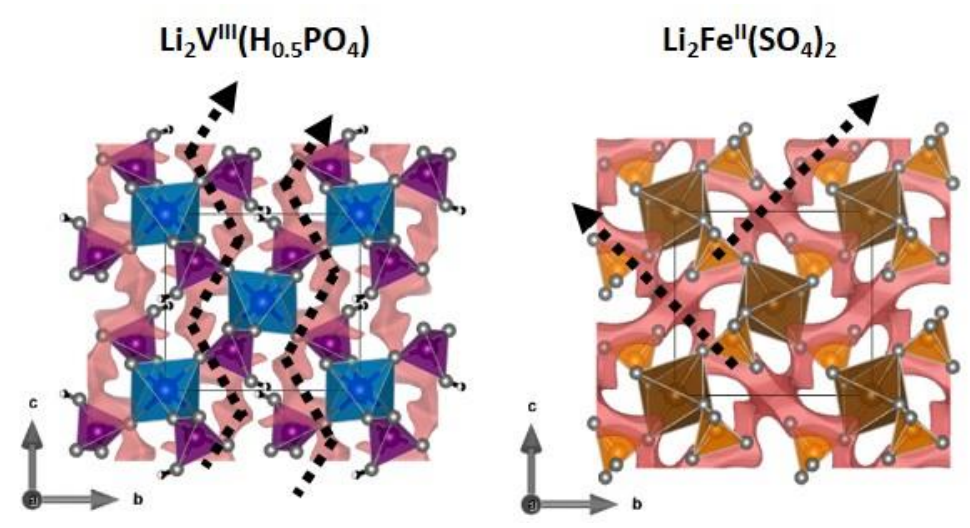

Tanks to precise structure determination using single crystal $\mathrm{x}$-ray diffraction and Bond Valence Energy Landscape methods, Li conduction pathways in the new material $\mathrm{Li}_{2} \mathrm{~V}\left(\mathrm{H}_{0.5} \mathrm{PO}_{4}\right)_{2}$ have been calculated and compared to those found in the closely related material $\mathrm{Li}_{2} \mathrm{Fe}\left(\mathrm{SO}_{4}\right)_{2}$. Because of hydrogen, in the title compound, Li diffusion occurs only along a zig zag direction parallel to the $\mathrm{c}$ axis 